Pittsburgh University School of Law

Scholarship@PITT LAW

2006

\title{
Homo Sacer, Homosexual: Some Thoughts on Waging Tax Guerrilla Warfare
}

Anthony C. Infanti

University of Pittsburgh School of Law, infanti@pitt.edu

Follow this and additional works at: https://scholarship.law.pitt.edu/fac_articles

Part of the Civil Rights and Discrimination Commons, Law and Economics Commons, Law and Gender Commons, Law and Society Commons, Sexuality and the Law Commons, and the Tax Law Commons

\section{Recommended Citation}

Anthony C. Infanti, Homo Sacer, Homosexual: Some Thoughts on Waging Tax Guerrilla Warfare, 2 Unbound: Harvard Journal of the Legal Left 27 (2006).

Available at: https://scholarship.law.pitt.edu/fac_articles/148

This Article is brought to you for free and open access by the Faculty Publications at Scholarship@PITT LAW. It has been accepted for inclusion in Articles by an authorized administrator of Scholarship@PITT LAW. For more information, please contact leers@pitt.edu, shephard@pitt.edu. 


\title{
Homo Sacer, Homosexual: Some Thoughts on Waging Tax Guerrilla Warfare
}

\author{
By Anthony C. Infanti*
}

In fact, it is now clear to most that the social and political forces now holding power are beyond simply opposing issues supportive to LGBT people and have now moved to open warfare against all that they hold in contempt, including and especially the LGBT community. It is then little surprise that LGBT communities are experiencing not only unprecedented attacks politically, but have also been living through an unprecedented and sustained increase in anti-LGBT violence.

- National Coalition of Anti-Violence Programs ${ }^{1}$

Questioning the ostensibly unquestionable premises of our way of life is arguably the most urgent of the services we owe our fellow humans and ourselves.

-Zygmunt Bauman ${ }^{2}$

\section{Tax Time}

I always find January depressing. It isn't the weather that gets me down, although the gray Pittsburgh skies and the frigid temperatures certainly can be trying. No, it's the constant barrage of mail from banks, mortgage companies, and my employer, all of whom are so thoughtfully providing me with the information that I need to complete my federal income tax return. ${ }^{3}$ Given the "ugh!" that is probably reverberating inside your head as

\footnotetext{
* Associate Professor of Law, University of Pittsburgh School of Law. I would like to thank Vivian Curran, David Herring, Leandra Lederman, Michael Madison, John Parry, Tom Ross, and Lu-in Wang for their comments on prior drafts of this essay. I would also like to thank the participants at the 2006 Critical Tax Theory Conference at Mercer University School of Law and the editors and staff at Unbound for their comments. In addition, I would like to thank Eliza Hall for her careful cite-checking of this essay. And, as always, I must thank Hiền for his unflagging love and support during the writing of this essay (read: for putting up with me while I spent - and spend - so much of my time "chewing books" instead of painting the house).

1 Nat'l Coalition of Anti-Violence Programs, Anti-Lesbian, Gay, Bisexual and TRANSGENDER VIOLENCE IN 2004, at 13-14 (2005) [hereinafter NCAVP 2004 REPORT], http:// www.ncavp.org/common/document_files/Reports/2004NationalHV\%20Report.pdf.

2 Zygmunt Bauman, Globalization: The Human Consequences 5 (1998).

${ }^{3}$ Well, they're not really being thoughtful; they're just complying with their legal obligation to send us all of these little pieces of paper. I.R.C. $\S \S 6041(\mathrm{~d}), 6049(\mathrm{c}), 6050 \mathrm{H}(\mathrm{d}), 6051(\mathrm{a})$ (2006);
} 
you read this, I'm sure that this plaint would sound trite if I weren't to immediately confess that I'm a "tax geek," someone who makes his living teaching and writing about the tax laws. ${ }^{4}$

Alas, I find tax time depressing for reasons different from most. To me, tax time is more than the occasion for fulfilling my obligation to defray a portion of the cost of government; it is an annual reminder of my difference - and of my oppression by the government because of that difference. Completing my federal income tax return reminds me that the government has singled out for condemnation my partner and me, my sister and her partner, and every other lesbian and gay man in the United States.

When the W-2s and 1099s begin to appear in my mailbox, I can't help but think how the federal government legally erased even the possibility of a relationship for me when it enacted the Defense of Marriage Act (DOMA). ${ }^{5}$ From the perspective of the federal government, my marriage to my partner in Toronto, Canada, never really happened - and, for that matter, never could happen. Each year, when tax season comes around, I feel the legal eraser scraping against me once again as the federal government returns to ensure that it has removed all trace of my relationship. As if to continually reaffirm its success in wiping away the connection between us (or, perhaps, because it never really can succeed), the federal government forces my partner and me to act as if we were total strangers by demanding that we file two "single" tax returns every April 15.6

But even within the diaphanous realm of federal tax law, we cannot truly be made "single." Because our lives are intertwined financially and emotionally, when the federal government designates us as legal strangers, it can, at most, banish us to that uncomfortable and uncertain space between "single" and "joint." Life in this tax "limbo"7 is in some ways more precarious than DOMA's outright condemnation would seem to indicate. In tax limbo, members of lesbian and gay couples are told what they are not (i.e., married), but they are never told what they are (and, concomitantly, how they should report transactions between them). The existence of this limbo opens the way for the federal government to visit further, more dehumanizing, indignities upon us: it allows the federal

Treas. Reg. $\S 1.6041-2(\mathrm{a})(5)$ (as amended in 2004); id. $\S 1.6049-6$ (as amended in 1999); id. $\S$ $1.6050 \mathrm{H}-2$ (b) (as amended in 2000); id. § 31.6051-1 (as amended in 2004).

${ }^{4}$ See http://www.law.pitt.edu/infanti/cv.htm for a list of the tax courses that I teach and a list of my publications.

${ }^{5}$ Defense of Marriage Act, Pub. L. No. 104-199, § 3(a), 110 Stat. 2419, 2419 (1996) (codified at 1 U.S.C. $\oint 7$ (2006)).

${ }^{6}$ InTERnAl REVEnUE SERV., U.S. DEP'T OF TrEaSURy, InSTRUCTIONS: Form 1040, at 1617 (2005), http://www.irs.gov/pub/irs-pdf/i1040.pdf. I have nonetheless taken to including an addendum in which I state that I am filing a "single" return under protest.

7 See Mark Schwanhausser, Domestic Partners in Tax-Return Limbo, San Jose Mercury News, Feb. 23, 2006, at 1A (this thought has clearly not occurred to me alone). I find it quite ironic that, even as the Roman Catholic Church moves toward abandoning the notion of limbo, it still manages to persist in the federal tax laws. Ian Fisher, Limbo, an Afterlife Tradition, May Be Doomed by the Vatican, N.Y. TIMES, Dec. 28, 2005, at A1. 
government to invade the sanctity of our homes - and of our relationships - to demand that we account for our every move, with our partners and with others, or suffer consequences that range from confiscatory monetary sanctions (i.e., interest, penalties, and, of course, interest on the penalties) to imprisonment. ${ }^{8}$

So, when the dreams of sugarplums in December give way to nightmares about what might better be termed the lesbian and gay circle of tax hell in January, ${ }^{9}$ I can't help but feel haunted by the voices of the reactionary congressmen who enacted DOMA as they repeatedly deprecate my relationship by referring to it as a "marriage" — with the quotation marks that mark it as a sham, a failed and hopelessly failing attempt at establishing a lasting, loving tie with another human being. ${ }^{10}$

\section{Homo Sacer and the State of Exception}

Fortunately, tax time this year has not felt quite so oppressive. I won't go so far as to say that it's been cheerful, but I certainly would say that it has been more thoughtful. A book suggested by a (now, unfortunately, former) Pitt Law colleague ${ }^{11}$ while we were chatting at the AALS annual meeting ${ }^{12}$ provoked me to reflect on this seasonal affliction ${ }^{13}$ and to approach it from a different perspective. The book, Homo Sacer: Sovereign Power and Bare Life by Giorgio Agamben, ${ }^{14}$ deals with biopolitics and the nature of sovereignty, two subjects that, at first blush, probably seem to have only the most tenuous of connections with the tax treatment of same-sex couples. But, if you hang on for just a few pages, I promise that you will begin to see the connection.

${ }^{8}$ See Anthony G. Infanti, The Internal Revenue Code as Sodomy Statute, 44 SANTA CLARA L. REV. 763, 790-800 (2004), for a detailed explanation of this point.

${ }^{9}$ Cf. Dante, The Divine Comedy: Hell, Purgatory, Heaven, at Hell, Canto 11, ll. 5051 (Peter Dale trans., Anvil Press Poetry 1996) (1472) (indicating that a separate ring of the seventh circle of hell is devoted to "Both Sodom and Cahors, and all who name/God with disparagement within their hearts").

10 See H.R. REP. No. 104-664 (1996), reprinted in 1996 U.S.C.C.A.N. 2905.

11 Thank you, John Parry!

12 Each January, the Association of American Law Schools - http://www.aals.org — holds a conference for law professors. In my limited experience, I seem to learn more from talking with colleagues in the hallways than from attending any of the panel presentations.

13 Tax affective disorder, maybe? See Nat'l Mental Health Assoc., Seasonal Affective Disorder, http://www.nmha.org/infoctr/factsheets/27.cfm (last visited Feb. 17, 2006) ("Some people suffer from symptoms of depression during the winter months, with symptoms subsiding during the spring and summer months. This may be a sign of Seasonal Affective Disorder (SAD). SAD is a mood disorder associated with depression episodes and related to seasonal variations of light.").

14 Giorgio Agamben, Homo Sacer: Sovereign Power and Bare Life (Daniel HellerRoazen trans., Stanford Univ. Press 1998) (1995) [hereinafter AgAmben, Homo SACER]. 
Although Agamben's writing can, at times, be abstruse, ${ }^{15}$ the title of his book quite clearly points us to the key, intertwined themes of his discussion: sovereign power and bare life (which, as we will see, is essentially synonymous with the figure of homo sacer [sacred man]). To provide needed background, I will briefly consider each of these concepts separately and then discuss the manner in which Agamben brings them together.

For Agamben, the basic paradox of sovereignty is that "the sovereign is, at the same time, outside and inside the juridical order." 16 In other words, the sovereign - and it's worth noting that Agamben does not confine his discussion to the conventional notion of "sovereign" as "monarch" or "absolute ruler"; for this purpose, it makes no difference what form the sovereign takes ${ }^{17}$ — has the power to decide both what is included in and what is excluded from the juridical order. The sovereign's power to suspend the juridical order - to declare what Agamben refers to as a "state of exception" - is an example of this power to carve out a sphere that is excluded from the juridical order and, therefore, not subject to regulation by law. ${ }^{18}$ The Bush Administration's position with respect to the

15 A quality that he shares with Jacques Derrida, whose writing is "notorious for lack of clarity." Vivian Grosswald Curran, Deconstruction, Structuralism, Antisemitism and the Law, 36 B.C. L. REV. 1, 7 (1994). To give you a flavor of Agamben's writing style, I have liberally sprinkled my footnotes with quotations from his texts. See Anthony C. Infanti, A Tax Crit Identity Crisis? Or Tax Expenditure Analysis, Deconstruction, and the Rethinking of a Collective Identity, 26 WHITTIER L. REV. 707, 749 n.170 (2005) (doing the same with Derrida's writings).

16 Agamben, Homo SACER, supra note 14, at 15.

The sovereign exception (as zone of indistinction between nature and right) is the presupposition of the juridical reference in the form of its suspension. Inscribed as a presupposed exception in every rule that orders or forbids something (for example in the rule that forbids homicide) is the pure and unsanctionable figure of the offense that, in the normal case, brings about the rule's own transgression (in the same example, the killing of a man not as natural violence but as sovereign violence in the state of exception).

Id. at 21 .

17 See id. at 30 ("The principle according to which sovereignty belongs to law, which today seems inseparable from our conception of democracy and the legal State, does not at all eliminate the paradox of sovereignty; indeed it even brings it to the most extreme point of its development.").

And only because biological life and its needs had become the politically decisive fact is it possible to understand the otherwise incomprehensible rapidity with which twentieth-century parliamentary democracies were able to turn into totalitarian states and with which this century's totalitarian states were able to be converted, almost without interruption, into parliamentary democracies .... [T] he only real question to be decided was which form of organization would be best suited to the task of assuring the care, control, and use of bare life. Once their fundamental referent becomes bare life, traditional political distinctions ... lose their clarity and intelligibility and enter into a zone of indistinction.

Id. at 122 .

18 Agamben traces the history of the state of exception in a more recent book, GIORGIO Agamben, State Of ExGePtion 1 1-22, 41-51 (Kevin Attell trans., Univ. of Chicago Press 2005) (2003) [hereinafter AgAmBEN, ExCEPTION]. 
legal status of the detainees held at Guantánamo Bay, Cuba is a clear example of a sovereign's declaration of such a state of exception. ${ }^{19}$

For Agamben, when the sovereign declares a state of exception, what the sovereign excludes from the juridical order is not merely cast out from it. Instead, Agamben posits a complex, continuing relationship between this exception and the general rule. ${ }^{20}$ In his view, "the exception does not subtract itself from the rule; rather the rule, suspending itself, gives rise to the exception." 21 Agamben sees the rule as abandoning the exception, but, nonetheless, still "maintaining itself in relation to the exception." 22 It is in this way that the rule "first constitutes itself as a rule." 23 In fact, Agamben questions whether one can truly say that the exception has been placed outside the juridical order, ${ }^{24}$ because the general rule (i.e., what is included within the juridical order) only really takes on meaning

19 U.S. Dep't of Defense, Detainees at Guantanamo Bay: The Legal Basis for Detaining Al Quaida and Taliban Combatants, http://www.defenselink.mil/news/Jan2006/d20060215legalbasis.pdf; see Rasul v. Bush, 542 U.S. 466 (2004); see also infra note 39 and accompanying text.

20 See Agamben, Homo SACER, supra note 14, at 17-18 ("[W] hat is excluded . . is not, on account of being excluded, absolutely without relation to the rule. On the contrary, what is excluded in the exception maintains itself in relation to the rule in the form of the rule's suspension. The rule applies to the exception in no longer applying, in withdrawing from it.").

${ }^{21} I d$. at 18.

${ }^{22} I d$.

${ }^{23} I d$.

24

If the exception is the structure of sovereignty, then sovereignty is not an exclusively political concept, an exclusively juridical category, a power external to law (Schmitt), or the supreme rule of the juridical order (Hans Kelsen): it is the originary structure in which law refers to life and includes it in itself by suspending it. Taking up Jean-Luc Nancy's suggestion, we shall give the name ban (from the old Germanic term that designates both exclusion from the community and the command and insignia of the sovereign) to this potentiality ... of the law to maintain itself in its own privation, to apply in no longer applying. The relation of exception is a relation of ban. He who has been banned is not, in fact, simply set outside the law and made indifferent to it but rather abandoned by it, that is, exposed and threatened on the threshold in which life and law, outside and inside, become indistinguishable. It is literally not possible to say whether the one who has been banned is outside or inside the juridical order. . . It is in this sense that the paradox of sovereignty can take the form "There is nothing outside the law." The originary relation of law to life is not application but Abandonment.

Id. at 28-29. Agamben's assertion at the end of the quoted passage that " $\mathrm{t}]$ here is nothing outside the law" ("«non c'è un fuori della legge»"), GIORGIO AGAMBEn, HOMO SAGER: IL POTERE SOVRANO E LA NUDA VITA 34 (1995) (many thanks to my former student, Joe Gulino, for confirming the translation), appears to be a paraphrasing of Jacques Derrida's famous statement "[t] here is nothing outside of the text [there is no outside-text; il n'y a pas de hors-texte]." JACQUES DERRIDA, OF Grammatology 158 (Gayatri Chakravorty Spivak trans., Johns Hopkins Univ. Press 3d ed. 1997) (1967). 
when it can be compared and contrasted with the exception (i.e., what has been excluded from the juridical order). ${ }^{25}$ Indeed, Agamben later pointedly states that the "[1]aw is made of nothing but what it manages to capture inside itself through the inclusive exclusion of the exceptio: it nourishes itself on this exception and is a dead letter without it." ${ }^{26}$ In elaborating on the content-giving function of the exception, Agamben quotes at length from Carl Schmitt's discussion of the structure and importance of the exception:

"The exception is more interesting than the regular case. The latter proves nothing; the exception proves everything. The exception does not only confirm the rule; the rule as such lives off the exception alone .... The exception explains the general and itself. And when one really wants to study the general, one need only look around for a real exception. It brings everything to light more clearly than the general itself. After a while, one becomes disgusted with the endless talk about the general - there are exceptions. If they cannot be explained, then neither can the general be explained. Usually the difficulty is not noticed, since the general is thought about not with passion but only with comfortable superficiality. The exception, on the other hand, thinks the general with intense passion." 27

With some understanding of Agamben's views on sovereign power and the state of exception, let us now turn to a brief discussion of "bare life" that will naturally lead us to the connection that Agamben makes between the two concepts. "Bare life" is exactly what it sounds like: "bare natural life - which is to say, the pure fact of birth." 28 In this regard, Agamben distinguishes bare life from political life, which is "a qualified life, a particular way of life." 29 For an illustration of the concept of bare life, think again of the Bush Ad-

25 See Agamben, Homo SACER, supra note 14, at 19 (indicating that the sovereign's decision regarding the exception "is the originary juridico-political structure on the basis of which what is included in the juridical order and what is excluded from it acquire their meaning."); see also id. at 17 ("Through the state of exception, the sovereign 'creates and guarantees the situation' that the law needs for its own validity.").

26 Id. at 27.

27 Id. at 16 (quoting Garl Schmitt, Politische Theologie: Vier Kapitel Zur Lehre VON DER SOUVERÄNITÄT 19-22 (1922)). Carl Schmitt was one of the foremost Nazi legal theorists, $i d$. at 169, and Agamben particularly draws on his work in discussing the concentration camp as the "pure space of exception." Id. at 134; see also id. at 169, 171, 175, 184.

It is also worth noting that Agamben's (and, in turn, Schmitt's) discussion of the "exception" is very similar to the deconstructionist notion of the "trace," which is the idea that "the terms in a hierarchical opposition rely for their coherence on the differentiation between them" and, therefore, each bear a "trace" of the other. J.M. Balkin, Deconstructive Practice and Legal Theory, 96 YALE L.J. 743, 752 (1987); see also DERRIDA, supra note 24, at 46-47. For further discussion of the "trace," see Infanti, supra note 15, at 756-57.

28 Agamben, Homo SACER, supra note 14, at 127.

${ }^{29} I d$. at 1 .

In the classical world, however, simple natural life is excluded from the polis in the strict sense, and remains confined - as merely reproductive life — to the sphere of the oikos, 'home.' . . . At the beginning of the Politics, Aristotle takes the greatest care to distinguish 
ministration's position with regard to the inmates at Guantánamo Bay, whom it wishes to strip of all political and legal rights and to reduce to mere living bodies. ${ }^{30}$

For Agamben, the Roman legal figure of homo sacer is the quintessential form of bare life. ${ }^{31}$ Homo sacer is the sacred man "who may be killed and yet not sacrificed." 32 To more fully describe the enigmatic figure of homo sacer, Agamben quotes from Pompeius Festus' treatise, On the Significance of Words:

"The sacred man is the one whom the people have judged on account of a crime. It is not permitted to sacrifice this man, yet he who kills him will not be condemned for homicide; in the first tribunitian law, in fact, it is noted that 'if someone kills the one who is sacred according to the plebiscite, it will not be considered homicide.' This is why it is customary for a bad or impure man to be called sacred." 33

To Agamben, homo sacer represents no more than a bare, nonpolitical life because his killing (by anyone) will not be legally punished as a homicide; yet, at the same time, neither can that killing be perpetrated using the machinery of the law (e.g., through the ritual practice of a trial followed by the imposition of the death penalty).

For precisely the same reason, homo sacer, the quintessential form of bare life, is likewise the embodiment of the state of exception. ${ }^{34}$ Homo sacer embodies the state of exception because the juridical order has been suspended with regard to him; again, neither will his killing be punished by the law, nor will it be effected under and through the law. Homo

the oikonomos (the head of an estate) and the despotes (the head of the family), both of whom are concerned with the reproduction and the subsistence of life, from the politician, and he scorns those who think the difference between the two is one of quantity and not of kind.

Id. at 2 .

One of the essential characteristics of modern biopolitics (which will continue to increase in our century) is its constant need to redefine the threshold in life that distinguishes and separates what is inside from what is outside. Once it crosses over the walls of the oikos and penetrates more and more deeply into the city, the foundation of sovereignty - nonpolitical life - is immediately transformed into a line that must be constantly redrawn.

Id. at 131 .

30 Agamben, Exception, supra note 18, at 4 ("in the detainee at Guantánamo, bare life reaches its maximum indeterminacy").

31 AgAmben, HOMO SACER, supra note 14, at 8 ("[ $\mathrm{t}$. he protagonist of this book[,] bare life, that is, the life of homo sacer (sacred man), who may be killed and yet not sacrificed").

${ }^{32} I d$.

${ }^{33} \mathrm{Id}$. at 71. Agamben describes homo sacer as an enigma because of the apparent contradiction in allowing a sacred man to be killed with impunity, so long as he was not "put to death according to ritual practices." Id. at 72.

34 See id. at 83 ("homo sacer presents the originary figure of life taken into the sovereign ban and preserves the memory of the originary exclusion through which the political dimension was first constituted"); see supra note 24 for a discussion of the sovereign ban. 
sacer has, in effect, been abandoned by the law - placed in a state of exception that gives meaning and content to that which is included within the juridical order.

Tracing the long (though veiled) history of the connection between bare life and the sovereign decision concerning the state of exception, ${ }^{35}$ Agamben argues that the production of bare life actually forms the very heart of sovereign power and is nothing less than the "originary 'political' relation." 36 According to Agamben, the only thing that is new to our era is the extent to which the state of exception "comes more and more to the foreground as the fundamental political structure and ultimately begins to become the rule," 37 rendering all of us virtual homines sacri who may at any time be designated by the sovereign as subject to being killed but not sacrificed. ${ }^{38}$

35 Using homo sacer as the paradigm, Agamben traces bare life as the originary political relation or element through the Roman vitae necisque potestas (i.e., "the unconditional authority [potestä] of the pater over his sons," AGAMBEN, HOMO SACER, supra note 14, at 87), the political body of the king and the figure of the devotus (i.e., one "who consecrates his own life to the gods of the underworld in order to save the city from a grave danger," $i d$. at 96), as well as the figure of the werewolf. $I d$. at 87-111. Continuing into the modern era, Agamben detects the presence of homo sacer in the 1679 writ of habeas corpus and the French Declaration of the Rights of Man and Citizen in 1789, id. at 123-35, in the status of refugees, $i d$. at 131-34, and in determining the time of death of comatose patients (such as Karen Quinlan), $i d$. at 160-65. Agamben's exploration of bare life and the state of exception culminates with a discussion of Nazi eugenics and the concentration camp as the "pure space of exception." Id. at 134; see id. at 136-59, 166-80.

36

What this work has had to record among its likely conclusions is precisely that the two analyses cannot be separated, and that the inclusion of bare life in the political realm constitutes the original - if concealed - nucleus of sovereign power. It can even be said that the production of a biopolitical body is the original activity of sovereign power. In this sense, biopolitics is at least as old as the sovereign exception. Placing biological life at the center of its calculations, the modern State therefore does nothing other than bring to light the secret tie uniting power and bare life, thereby reaffirming the bond . . . between modern power and the most immemorial of the arcana imperii.

Id. at 6 .

If our hypothesis is correct, sacredness is . . the originary form of the inclusion of bare life in the juridical order, and the syntagm homo sacer names something like the originary 'political' relation, which is to say, bare life insofar as it operates in an inclusive exclusion as the referent of the sovereign decision.

Id. at 85; see also AGAMBEN, EXCEPTION, supra note 18, at 87-88 ("Bare life is a product of the machine and not something that preexists it, just as law has no court in nature or in the divine mind.").

37 Agamben, HOMO SACER, supra note 14, at 20.

38

And if in modernity life is more and more clearly placed at the center of State politics (which now becomes, in Foucault's terms, biopolitics), if in our age all citizens can be said, in a specific but extremely real sense, to appear virtually as homines sacri, this is possible only 


\section{The Lesbian and Gay Exception}

Despite the endless "war on terror" and the extraordinary powers arrogated by the President in its name (e.g., warrantless wiretapping, secret CIA detention centers, and the torture perpetrated at the prisons at Guantánamo Bay and Abu Ghraib) as well as the government intervention in the Terri Schiavo case, ${ }^{39}$ most Americans would probably find it difficult to accept Agamben's assertion that we now live in a permanent state of exception and are all virtually homines sacri. I imagine, however, that most lesbians and gay men would, like me, readily identify with the figure of homo sacer. 40

Like homo sacer, lesbians and gay men are the exception that gives meaning and content to the general rule that is heterosexual privilege. Naturally, heterosexuals encounter difficulties seeing the pervasiveness of their privilege because they live and breathe the general rule. They cannot see the ease with which they speak of husbands and wives or parents and children (all of whom share in common the links of heterosexual reproductive activity) or the brazen way that they celebrate their marriages, openly wear their wedding rings, and display photos of their families at work. It is only when heterosexuals directly confront the lesbian and gay exception ${ }^{41}$ - for example, the very real instance of the lesbian who lost her job for participating in a religious wedding ceremony with her partner ${ }^{42}$

because the relation of ban has constituted the essential structure of sovereign power from the beginning.

Id. at 111 ; see also id. at 124 ("modern democracy does not abolish sacred life but rather shatters it and disseminates it into every individual body, making it into what is at stake in political conflict"); $i d$. at 140 ("Bare life is no longer confined to a particular place or a definite category. It now dwells in the biological body of every living being.").

39 See generally AgAmBen, ExCEPTION, supra note 18, at 3-4, 22; Slavoj Žižek, Biopolitics: Between Terri Schiavo and Guantanamo, ARTFORUM, Dec. 2005, at 270, available at http://www.lacan.com/ zizartforum1205.htm; Eric L. Santner, Terri Schiavo and the State of Exception, http://www.press. uchicago.edu/Misc/Chicago/05april_santner.html (last visited Feb. 9, 2006).

40 I disagree with Agamben's conditional assertion that "[i]f today there is no longer any one clear figure of the sacred man, it is perhaps because we are all virtually homines sacri." AGAMBEN, HOMO SACER, supra note 14, at 115. At the very least, and as explained more fully in the text below, lesbians and gay men are today a "clear figure of the sacred man." And, as Alice Thomas pointed out to me, members of other oppressed groups may fit this description as well.

${ }^{41}$ Commentators have, in fact, spoken of the "gay exception" to various legal rules. See, e.g., Arthur S. Leonard, Boy Scouts of America v. Dale: The "Gay Rights Activist" as Constitutional Pariah, 12 Stan. L. \& Pol'y Rev. 27, 32 (2001); Tobias Barrington Wolff, Political Representation and Accountability Under Don't Ask, Don't Tell, 89 IowA L. REv. 1633, 1710 \& n.319 (2004); Evan Wolfson, Marriage Equality and Some Lessons for the Scary Work of Winning, 14 LAW \& SEXUALITY 135, 139 (2005).

${ }^{42}$ Shahar v. Bowers, 114 F.3d 1097 (11th Cir. 1997). The federal appeals court upheld the decision of the Georgia attorney general to withdraw the job offer on the ground that the attorney general could reasonably conclude that the decision of one of his employees to "marry" another 
- that heterosexuals have occasion to realize the meaning and extent of their privilege. In contrast, for lesbians and gay men, it seems that heterosexual privilege is both everpresent and inescapable. We cannot help but constantly be faced with the ways in which we are treated as the exception to the heterosexual rule.

In the Internal Revenue Code, lesbians and gay men served for decades as the unspoken foils for heterosexual married couples. Lesbians and gay men were the irreducible singles - the confirmed bachelor or maiden aunt - the singles who would never (and could never) get married.43 By enacting DOMA, Congress did no more than set the general rule down in writing: "'marriage' means only a legal union between one man and one woman as husband and wife." 44 And, in an area where the government acquires

woman would confuse the public, would cause the public to question his office's credibility, would interfere with his office's ability to handle the enforcement of the Georgia sodomy law, and would form a reasonable basis for the attorney general to lose confidence in that employee's "ability to make good judgments as a lawyer for the Law Department." Id. at 1110.

43 Unless, of course, they were to accede to social pressure and marry someone of the "opposite" sex in order to pass as straight.

441 U.S.C. $§ 7$ (2006). As my colleague Vivian Curran pointed out to me, the sociologist Zygmunt Bauman would likely argue that Congress did more than simply set the general rule down in writing; it exerted the only power that it has left in our "globalized" world - the power to repress the weak and vulnerable. (I place the word "globalized" in quotation marks because, as Bauman notes, the more the word "globalization" is used, the less it really seems to signify. BAUMAN, supra note 2 , at 1 .)

In the course of exploring the "social roots and social consequences of the globalizing process," $i d$., Bauman discusses the erosion or withering away of the nation-state in the wake of globalization. Id. at 56-69. The effects of this erosion or withering away are captured in a trenchant quote that Bauman takes from Subcomandante Marcos, the head of the rural rebellion in Chiapas, Mexico: "In the cabaret of globalization, the state goes through a strip-tease and by the end of the performance it is left with the bare necessities only: its powers of repression." Id. at 66 (quoting Sous-Commandant Marcos, Sept pièces du puzzle néolibéral: la quatrième guerre mondiale a commencé, LE MONDE DIPLOMATIQUE, Aug. 1997, at 4-5). In Bauman's words, all that is left to the nation-state is its ability to "focus locally on the 'safe environment' and everything it may genuinely or putatively entail." Id. at 120. To justify its continued existence, the government thus demonizes those at the bottom of society and, for the sake of enhancing the personal safety of those at the top (and, concomitantly, to alleviate their feelings of insecurity and uncertainty, which are so often conflated with notions of personal safety), passes laws criminalizing activity engaged in by those at the bottom - the same activity that continues to be freely engaged in by those at the top. Id. at 113-27. The lesbian and gay movement evokes similar feelings of insecurity and uncertainty in much of straight society, and DOMA (along with its many state law counterparts) can be conceptualized as the government's attempt to justify its continued existence by securing the "safety" of "traditional" marriage from the threat posed by same-sex marriage - indeed, viewed from this perspective, is it any wonder that reactionary politicians incessantly speak of "defending" or "protecting" marriage? See, e.g., Press Release, Office of the Press Sec'y, The White House, President Calls for Constitutional Amendment Protecting Marriage (Feb. 24, 2004), http://www.whitehouse.gov/news/ releases/2004/02/20040224-2.html. 
such sensitive information about individuals that its interactions are shielded from public view, ${ }^{45}$ heterosexual married couples are afforded a privileged zone of privacy in which even the Internal Revenue Service (Service) will not enter. ${ }^{46}$ But again, this general rule means nothing until it is juxtaposed with the unstated, yet implicit exception: the lesbians and gay men who, shorn of any euphemisms, are now irreducibly and irretrievably single, and whose relationships, far from being afforded privacy, are subject to intense government scrutiny. ${ }^{47}$

And, like homo sacer, each lesbian and gay man has been reduced to a bare life, one that may be killed but not sacrificed. We are no longer put to death by the "sanctioned ritual practices" 48 of the state simply for being homosexual; that barbarity was left behind long ago. ${ }^{49}$ But the state's pervasive marking of us as the exception to the general rule of heterosexual privilege does open the space for individuals to attack and kill us with impunity. As research psychologist Dr. Gregory Herek has observed:

Whereas psychological heterosexism [i.e., the manifestation of heterosexism in an individual's actions and attitudes $]^{50}$ may not always be the principal reason for an anti-gay attack (e.g., a gang might well have selected another type of "outsider" as a suitable victim), the importance of cultural heterosexism [i.e., the manifestation of heterosexism in societal customs and institutions $]^{51}$ cannot be underestimated. For it is cultural heterosexism that defines gay people as suitable targets that can be "used" for meeting a variety of psychological needs. And anti-gay attacks, regardless of the perpetrator's motivation, reinforce cultural heterosexism. Thus, when a teenage gang member attacks a gay man on the street, it is a hate crime not because hate necessarily was the attacker's primary motive (it may or may

${ }^{45}$ I.R.C. $§ 6103$ (2006).

46 See id. $\S \S 1041,2056,2523$. These provisions work together to essentially treat the heterosexual married couple as a single economic unit. For federal tax purposes, any transactions occurring within that economic unit are of no consequence, and, as a result, the Service has no need to look into them. In this way, Congress has clearly marked out the boundaries of a privileged zone of privacy in the tax laws for heterosexual married couples.

47 See supra note 8 and accompanying text.

48 Agamben, HOMO SACER, supra note 14, at 89.

${ }^{49}$ During the colonial period in New England, sodomy was punishable by death. BYRNE FONE, Homophobia: A History 329 (2000). There are records of men being executed as well as records of men being severely whipped, burned with a hot iron, and then made permanent outcasts for engaging in homosexual activity. $I d$. at 329,331 . In the eighteenth century, the United States ignored the continental European trend toward decriminalization of sodomy; however, many U.S. states did abolish the death penalty for homosexual activity. Id. at 332.

${ }^{50}$ Gregory M. Herek, Pyschological Heterosexism and Anti-Gay Violence: The Social Psychology of Bigotry and Bashing, in Hate Crimes: Confronting Violence Against Lesbians and Gay Men 149, 151 (Gregory M. Herek \& Kevin T. Berrill eds., 1992) [hereinafter HATE CRIMES: Confronting VIOLENCE].

${ }^{51}$ Gregory M. Herek, The Social Context of Hate Crimes: Notes on Cultural Heterosexism, in HaTE CRIMES: CONFRONTING VIOLENCE, supra note 50, at 89, 89. 
not have been) but because the attack expresses cultural hostility, condemnation, and disgust toward gay people and because it has the effect of terrorizing the individual victim as well as the entire lesbian and gay community. The attack in effect punishes the gay person for daring to be visible. ${ }^{52}$

Although this observation was made more than a decade ago, it could just as aptly have been made today. Anti-gay violence persists at high levels in American society. When adjusted for population size, lesbians and gay men report higher rates of bias crimes than do African-Americans or Jewish people, and they report significantly more crimes against the person than either of those groups. ${ }^{53}$ Disturbingly, it appears that antigay violence spikes whenever the lesbian and gay community finds itself in the spotlight.

Consider, by way of example, the years 2003 and 2004: In the geographic area covered by the National Coalition of Anti-Violence Programs (which includes less than 30\% of the national population), ${ }^{54}$ the number of incidents of violence against gay men, lesbi-

\footnotetext{
${ }^{52}$ Herek, supra note 50, at 164; see also Karen Franklin, Unassuming Motivations: Contextualizing the Narratives of Antigay Assailants, in STIGMA AND SEXUAL ORIENTATION: UNDERSTANDING Prejudice Against Lesbians, Gay Men, and Bisexuals 1, 20 (Gregory M. Herek ed., 1998) ("antigay violence can be seen primarily as an extreme manifestation of pervasive cultural norms rather than as a manifestation of individual hatred").

53 William B. Rubenstein, The Real Story of U.S. Hate Crimes Statistics: An Empirical Analysis, 78 TUL. L. REV. 1213, 1232 (2004). It is worth noting that Rubenstein's analysis uses the bias crime statistics compiled by the Federal Bureau of Investigation. As described infra note 54, these statistics only reflect reported bias crimes and therefore understate the total number of bias crimes that occur in the United States each year.

54 NCAVP 2004 REPORT, supra note 1, at 18 (stating that the report covers "approximately $27 \%$ of the nation's population" (citation omitted)); NAT'L COALITION OF ANTI-VIOLENGE Programs, Anti-Lesbian, Gay, Bisexual and Transgender Violence in 2003, at 18-19 (2004), http://www.ncavp.org/common/document_files/Reports/2003NCAVP_HV_Report.pdf (stating that the report covers "29.3\% of the nation's population") [hereinafter NGAVP 2003 REPORT]. The Federal Bureau of Investigation (FBI) also reports bias crime statistics, including statistics with respect to crimes that are motivated by sexual orientation bias; however, these reports significantly underreport the level of anti-gay violence in the United States. The FBI report for 2003, which covers a geographic area including nearly $83 \%$ of the national population, only reported 1,239 incidents of violence motivated by sexual orientation bias, which is far below the number of incidents reported by the National Coalition of Anti-Violence Programs with respect to a far smaller portion of the national population. FED. BUREAU OF INVESTIGATION, U.S. DEP'T OF Justice, Hate CRime Statistics: 2003, at 1, 9 (2004), available at http://www.fbi.gov/ucr/ 03hc.pdf; see also NCAVP 2003 REPORT, supra, at 18-19. The FBI's underreporting of sexual orientation-motivated bias crimes has been attributed to a number of factors, including the victim's desire not to be outed and lesbians' and gay men's general distrust of the police due to a history of harassment at their hands. Donald Altschiller, Hate Crimes: A Reference HandboOk 27-28 (2d ed. 2005).
} 
ans, bisexuals, and transgender individuals increased 8\% from 2002 to $2003^{55}$ and increased an additional 4\% from 2003 to $2004 .{ }^{56}$ Although there was a $4 \%$ decrease in the number of victims suffering injuries in 2003, the number of victims suffering serious injuries rose $3 \%, 57$ and the number of murder victims rose $80 \%$ (from 10 in 2002 to 18 in 2003). 58 Again in 2004, despite a $2 \%$ decrease in the number of victims suffering injuries, ${ }^{59}$ the number of victims suffering serious injuries rose an astounding $20 \% 60$ and the number of murder victims rose $11 \%$ (to 20 in 2004). ${ }^{61}$ Providing support for the existence of a "spotlight" effect, there was a noticeable spike in anti-gay violence in the latter half of 2003, when the decisions in Lawrence v. Texas ${ }^{62}$ (striking down Texas' sodomy statute) and Goodridge v. Department of Public Health ${ }^{63}$ (extending the right to marry to same-sex couples in Massachusetts) were issued, and that spike continued into the first half of $2004 .{ }^{64}$

The ability to physically menace and even kill lesbians and gay men with impunity stems in part from the fact that these crimes often go unreported - out of fear of further harassment from the police. ${ }^{65}$ Even when these crimes are reported, advocacy groups find it necessary to press for the investigation of complaints. ${ }^{66}$ And, despite the best efforts of those advocacy groups, most bias crimes against lesbians and gay men go legally unpunished. For example, according to the National Coalition of Anti-Violence Programs, in 2004, there was an $82 \%$ increase in the number of bias crime complaints that police refused to take, and $66 \%$ of the bias crime complaints that were taken resulted in

55 NCAVP 2003 REPORT, supra note 54, at 21. This represented a reversal of a general downward trend in anti-gay violence over the previous five-year period, which was part of the general decrease in crime nationally - although anti-gay violence "did not fall as far or as rapidly as violent crime in general" during that period. Id. at 16.

56 NGAVP 2004 REPORT, supra note 1, at 24.

57 NGAVP 2003 REPORT, supra note 54, at 4.

$58 \mathrm{Id}$. at 21 .

59 NCAVP 2004 REPORT, supra note 1, at 27.

${ }^{60} \mathrm{Id}$.

61 Id. at 25.

62539 U.S. 558 (2003).

63798 N.E.2d 941 (Mass. 2003).

64 NCAVP 2004 REPORT, supra note 1, at 16; NCAVP 2003 REPORT, supra note 54, at 15. This paralleled earlier spikes: first, in New York City in June 1994, when that city hosted both the Gay Games and the Stonewall 25 celebration, and then nationally in March and April 1997, when Ellen DeGeneres and her character on her eponymous television show simultaneously came out of the closet. NGAVP 2003 REPORT, supra note 54, at 14.

65 NCAVP 2004 REPORT, supra note 1, at 43.

${ }^{66} I d$. ("Often in the experience of NCAVP members, even victims of brutal anti-LGBT assaults will hesitate to file police reports, and for those who do, a good portion of the services that NCAVP agencies provide is concerned with persuading police to act on their complaints in a meaningful way."). 
no arrest (and, therefore, no legal punishment). ${ }^{67}$ It should come as little surprise then to hear reports of reactionaries blithely calling for an "open season" on lesbians and gay men. ${ }^{68}$

\section{Of Parables and Provocateurs}

As homines sacri living in a virtual state of exception, ${ }^{69}$ lesbians and gay men should be particularly interested in Agamben's interpretation of Franz Kafka's parable Before the Law, which Kafka later incorporated into chapter nine of his book The Trial. It is worth reproducing this short parable in full before considering Agamben's interpretation of it:

[B] efore the Law stands a doorkeeper. To this doorkeeper there comes a man from the country who begs for admittance to the Law. But the doorkeeper says that he cannot admit the man at the moment. The man, on reflection, asks if he will be allowed, then, to enter later. "It is possible," answers the doorkeeper, "but not at this moment." Since the door leading into the Law stands open as usual and the doorkeeper steps to one side, the man bends down to peer through the entrance. When the doorkeeper sees that, he laughs and says: "If you are so strongly tempted, try to get in without my permission. But note that I

67 Id. at 44 .

68 Bob Hague, Voicemail Message Suggests "Open Season" on Gays (Wis. Radio Network Dec. 6, 2005), http://www.wrn.com/gestalt/go.cfm?objectid=E78DA9DB-FA31-41FE-835BAA01D956 B977\&dbtranslator=local.cfm (containing a story about, as well as a link to, a voicemail message that called for an "open season" on lesbians and gay men; the message had been left for a state legislator on the eve of a debate about same-sex marriage); see also Boyd County High Sch. Gay Straight Alliance v. Bd. of Educ., 258 F. Supp. 2d 667, 670 n.1 (E.D. Ky. 2003) ("One example of the harassment includes students in . . English class stating that they needed to take all the fucking faggots out in the back woods and kill them."); AM. CiviL LiBERTIES UNION, 2006 WORKPLAN 6 (2006) (on file with author) (in speaking of the same school, stating that "[t]he anti-harassment training part of the settlement was important because there was widespread anti-gay harassment in the school, and teachers and administrators were doing little to stop it. For example, the school's Model United Nations once adopted a resolution declaring an 'open hunting season' on gay students.").

69 Agamben explains the notion of the "virtual" state of exception more fully in AGAMBEN, EXCEPTION, supra note 18. As explained there, the virtual state of exception is a suspension of the juridical order in the face of a fictitious threat (as opposed to a "real" state of exception, which is a suspension of the juridical order in the face of a real threat). Id. at 3 ("[T] he distinction between a 'real state of exception' (état de siège effectif) and a 'fictitious state of exception' (état de siège fictif) goes back to the French public law theory ...."), 4 ("Though the notions of state of siege and martial law express a connection with the state of war that has been historically decisive and is present to this day, they nevertheless prove to be inadequate to define the proper structure of the phenomenon, and they must therefore be qualified as political or fictitious . . . The history of the term fictitious or political state of siege is instructive .... It goes back to the French doctrine that . . provided for the possibility of a state of siege that the emperor could declare whether or not a city was actually under attack or directly threatened by enemy forces .....”). 
am powerful. And I am only the lowest doorkeeper. From hall to hall, keepers stand at every door, one more powerful than the other. And the sight of the third man is already more than even I can stand." These are difficulties which the man from the country has not expected to meet, the Law, he thinks, should be accessible to every man and at all times, but when he looks more closely at the doorkeeper in his furred robe, with his huge, pointed nose and long, thin, Tartar beard, he decides that he had better wait until he gets permission to enter. The doorkeeper gives him a stool and lets him sit down at the side of the door. There he sits waiting for days and years. He makes many attempts to be allowed in and wearies the doorkeeper with his importunity. The doorkeeper often engages him in brief conversation, asking him about his home and about other matters, but the questions are put quite impersonally, as great men put questions, and always conclude with the statement that the man cannot be allowed to enter yet. The man, who has equipped himself with many things for his journey, parts with all he has, however valuable, in the hope of bribing the doorkeeper. The doorkeeper accepts it all, saying, however, as he takes each gift: "I take this only to keep you from feeling that you have left something undone." During all these long years the man watches the doorkeeper almost incessantly. He forgets about the other doorkeepers, and this one seems to him the only barrier between himself and the Law. In the first years he curses his evil fate aloud; later, as he grows old, he only mutters to himself. He grows childish, and since in his prolonged study of the doorkeeper he has learned to know even the fleas in his fur collar, he begs the very fleas to help him and to persuade the doorkeeper to change his mind. Finally his eyes grow dim and he does not know whether the world is really darkening around him or whether his eyes are only deceiving him. But in the darkness he can now perceive a radiance that streams inextinguishably from the door of the Law. Now his life is drawing to a close. Before he dies, all that he has experienced during the whole time of his sojourn condenses in his mind into one question, which he has never yet put to the doorkeeper. He beckons the doorkeeper, since he can no longer raise his stiffening body. The doorkeeper has to bend far down to hear him, for the difference in size between them has increased very much to the man's disadvantage. "What do you want to know now?" asks the doorkeeper, "you are insatiable." "Everyone strives to attain the Law," answers the man, "how does it come about, then, that in all these years no one has come seeking admittance but me?" The doorkeeper perceives that the man is nearing his end and his hearing is failing, so he bellows in his ear: "No one but you could gain admittance through this door, since this door was intended for you. I am now going to shut it."70

For Agamben, the man from the country in this parable is akin to homo sacer; he is living in a virtual state of exception. The law can be seen as holding the man from the country in a relation of exception:"11 the "law applies to him in no longer applying, and holds him in its ban in abandoning him outside itself. The open door destined only for him includes him in excluding him and excludes him in including him.”72 Remarkably,

70 Franz KafkA, The Trial 213-15 (Willa \& Edwin Muir trans., Schocken Books 1968) (1925).

71 AgAmben, Homo SACER, supra note 14, at 50.

${ }^{72} \mathrm{Id}$. 
in the state of exception, the law's abandonment of the man from the country only makes its effect upon him all the more powerful:

For life under a law that is in force without signifying resembles life in the state of exception, in which the most innocent gesture or the smallest forgetfulness can have most extreme consequences. And it is exactly this kind of life that Kafka describes, in which law is all the more pervasive for its total lack of content, and in which a distracted knock on the door can mark the start of uncontrollable trials.... [S]o in Kafka's village the empty potentiality of law is so much in force as to become indistinguishable from life. ${ }^{73}$

Agamben describes the real danger that faces each of us in this state of exception that becomes indistinguishable from (consumes?) our life as the possibility that we might find ourselves "condemned to infinite negotiations with the doorkeeper or, even worse, that [we] might end by [ourselves] assuming the role of the doorkeeper who, without really blocking the entry, shelters the Nothing onto which the door opens." 74

Probably the most striking aspect of Agamben's analysis of Kafka's parable, however, is his treatment of its ending. Agamben does not see in this ending "the irremediable failure or defeat of the man from the country before the impossible task imposed upon him by the Law."75 When the doorkeeper closes the door that was open only to the man from the country, Agamben "imagine[s] that all the behavior of the man from the country is nothing other than a complicated and patient strategy to have the door closed in order to interrupt the Law's being in force."76 Thus, instead of failure, Agamben sees success, "even if [the man from the country] may have risked his life in the process (the story does not say that he is actually dead but only that he is 'close to the end')." 77 Recapitulating the end of the parable in messianic terms, Agamben essentially contends that deliverance comes only once the man from the country provokes the closure of the door to the law when he is no longer a virtual "outlaw" but a very real one:

${ }^{73} I d$. at $52-53$ (emphasis added).

${ }^{74} \mathrm{Id}$. at 54 .

${ }^{75} \mathrm{Id}$. at 55. In this regard, Agamben distinguishes his interpretation from that of Derrida, who sees in this ending the defeat of the man from the country:

At the moment when the man comes to his end, just before his death, the doorkeeper points out to him that he will not reach his destination, or that it will not reach him. The man comes to his end without reaching his end. The entrance is destined for and awaits him alone; he arrives there but cannot arrive at entering; he cannot arrive at arriving. Thus runs the account of an event which arrives at not arriving, which manages not to happen.

JaGques Derrida, Before the Law, in ACTS OF Literature 181, 210 (Derek Attridge ed., 1992) (footnote omitted); see AGAMBEN, HOMO SACER, supra note 14, at 57 (distinguishing Derrida's interpretation).

76 Agamben, Homo SACER, supra note 14, at 55.

${ }^{77} I d$. 
If one gives the name 'provocation' to the strategy that compels the potentiality of Law to translate itself into actuality, then his is a paradoxical form of provocation, the only form adequate to a law that is in force without signifying and a door that allows no one to enter on account of being too open. The messianic task of the man from the country ... might then be precisely that of making the virtual state of exception real, of compelling the doorkeeper to close the door of the Law . . . . For the Messiah will be able to enter only after the door is closed, which is to say, after the Law's being in force without significance is at an end .... . T ] he messianic aporias of the man from the country express exactly the difficulties that our age must confront in attempting to master the sovereign ban. ${ }^{78}$

Finally, in closing his discussion of the parable, Agamben underscores the idea that he is not advocating surrender to the power of the state of exception; instead, following the example set by the man from the country, he urges resistance to it and, ultimately, the subversion of it. 79

\section{Tax Guerrilla Warfare}

Agamben's view of sovereignty — as founded upon force and not upon a "contract or convention" 80 — should occasion lesbians and gay men to rethink their relationship with

\footnotetext{
${ }^{78} \mathrm{Id}$. at $56-57$.

${ }^{79} \mathrm{Id}$. at $57-58$.

$80 \mathrm{Id}$. at 109.
}

The time has come, therefore, to reread from the beginning the myth of the foundation of the modern city from Hobbes to Rousseau. The state of nature is, in truth, a state of exception, in which the city appears for an instant (which is at the same time a chronological interval and a nontemporal moment) tanquam dissoluta. The foundation is thus not an event achieved once and for all but is continually operative in the civil state in the form of the sovereign decision. What is more, the latter refers immediately to the life (and not the free will) of the citizens, which thus appears as the originary political element, the Urphänomen of politics. Yet this life is not simply natural reproductive life, the $z o \bar{e}$ of the Greeks, nor bios, a qualified form of life. It is, rather, the bare life of homo sacer and the wargus, a zone of indistinction and continuous transition between man and beast, nature and culture.

Id.

The violence that Benjamin defines as divine is instead situated in a zone in which it is no longer possible to distinguish between exception and rule. It stands in the same relation to sovereign violence as the state of actual exception, in the eighth thesis, does to the state of virtual exception. This is why (that is insofar as divine violence is not one kind of violence among others but only the dissolution of the link between violence and law) Benjamin can say that divine violence neither posits nor conserves violence, but deposes it. Divine violence shows the connection between the two violences - and even more, between violence and law - to be the single real content of law.

Id. at 65 . 
the law. It should cause us to question our past - albeit quite natural — privileging of legal approaches for achieving social change: ${ }^{11}$

For many of us who have suffered oppression or discrimination in any form it is easy to understand the attraction of rights-based approaches. Civil rights initiatives have an immediate, concrete appeal. They promise to secure the basic constitutional rights that lesbians and gay men have previously lived without: freedom from discrimination in areas such as housing, employment, child custody, military service, legal marriage, and spousal benefits. For individuals who live in a country that ostensibly provides these protections to all of its citizens, yet in practice denies them to particular groups, the simple granting of such rights often seems like the ultimate luxury: all we can hope for and, at the same time, too much to hope for. ${ }^{82}$

While alluring, this legal approach has proved to be both paralyzing and assimilationist. Too often, we do no more than sit idly outside the already open door to the law. We dare not approach the doorkeeper until we receive word from the legal "experts" that the "right" or "best" case with the most "sympathetic" plaintiff has arrived. 83 These experts actively discourage anyone who does not fit this ambiguous paradigm - which serves as a repository for every (real or imagined) heterosexual expectation of our non-threatening

${ }^{81}$ E.g., Ellen Ann ANDERsen, Out OF THE Closets \& INTO THE Courts 3, 17-26 (2005); Jules Lobel, Courts as Forums for Protest, 52 UCLA L. REv. 477, 479 (2004) ("The reform upsurge of the 1960s and 1970s witnessed a transformation in the role of the judiciary, particularly the federal judiciary. Courts were now often viewed not merely as forums to settle private disputes, but as instruments of societal change."); William B. Rubenstein, Divided We Litigate: Addressing Disputes Among Group Members and Lawyers in Civil Rights Campaigns, 106 YALE L.J. 1623, 1632 (1997) (describing impact litigation and test cases as cases that "are brought with the intention of establishing a legal precedent that will improve a group's social situation"). This privileging is implicit in the ubiquitous references to the "lesbian and gay rights movement." The alternative, more general phrase "lesbian and gay movement" does not limit collective action solely to the attainment of "rights."

82 Diane Helene Miller, Freedom to Differ: The Shaping of the Gay and Lesbian Struggle for Civil Rights 140 (1998); see also Patricia A. Cain, Rainbow Rights: The Role of LaWyers and Courts in the Lesbian and Gay Civil Rights Movement 1 (2000) ("The role of the lawyers, the legal arguments they construct, and the fine-tuning of these arguments in response to judicial opinions is a central part of any civil rights movement. . . Whether one believes that courts do in fact cause social change, courts are nonetheless crucial in any battle over equal rights.").

${ }^{83}$ Rubenstein, supra note 81 , at 1656 (citing as "one of the central complaints about social movements: overreliance on 'experts' (lawyers)"); see also, e.g., ANDERSEN, supra note 81, at 85-86 (discussing the choice between pursuing Bowers v. Hardwick or Baker v. Wade in terms of who would be a more "sympathetic" plaintiff); id. at 128-29 (similar discussion with regard to Lawerence $v$. Texas); id. at 186-87 (gay rights organizations issued a pamphlet discouraging individuals from filing same-sex marriage lawsuits in the wake of Baker v. Vermont, except in "'the best cases in the best places at the best times"'). 
domestication ${ }^{84}$ - from even considering the possibility of approaching the doorkeeper. ${ }^{85}$ When an ostensibly "good" case finally does happen by, the experts stand and bicker over whether this is truly the right case and the right time to approach the doorkeeper to plead for entrance through the already open door to the law. ${ }^{86}$ In the meantime, we sit by suffering needlessly. And pity the poor troublemaker who, on a rare occasion, challenges the experts' judgment and moves to plead her case directly to the doorkeeper; this rogue soon finds the experts attempting to intercept and block her approach for fear that the doorkeeper will bar the way to all. ${ }^{87}$ Thus, it seems that, despite (because of?) our best efforts, we have realized precisely the danger that Agamben warned of: rather than devoting our energy to fight our oppression under the law, most of us stand immobilized while

${ }^{84}$ See Devon W. Carbado, Black Rights, Gay Rights, Civil Rights, 47 UCLA L. Rev. 1467, 1505$06 \&$ n.148 ("Part of a civil rights strategy involves selecting the 'right' (read: most palatable) plaintiffs."), 1505-17 (exploring gay rights advocates' choice to use the stories of white lesbians and gay men in challenging the military's anti-gay policies while they ignored the story of an AfricanAmerican man who was the first to mount a successful challenge to those policies); cf. Suzanne B. Goldberg, On Making Anti-Essentialist and Social Constructionist Arguments in Court, 81 OR. L. REV. 629, 661 n. 117 (2002) (indicating that during her time at Lambda Legal Defense and Education Fund an effort was made to obtain a diverse group of plaintiffs when challenging sodomy laws and antigay measures).

85 For example, Gay and Lesbian Advocates and Defenders discouraged married same-sex couples from Massachusetts from filing joint tax returns in order to fight the discrimination against them in the federal tax laws, because it was not "looking to pick a fight with the IRS." Gay Newlyweds in Massachusetts Tackle Taxes, ADvOCATE, Jan. 26, 2005, http://www.advocate.com/ news_ detail_ektid03009.asp.

86 See Rubenstein, supra note 81, at 1635-44 (providing examples of how lesbian and gay civil rights litigation has divided the community within itself (over the appropriate goals of such litigation) and divided the lawyers who are prosecuting this litigation (over the methods for achieving these goals)).

${ }^{87}$ For example, several lesbian and gay rights organizations "are doing whatever they can to stop" a lawsuit brought by an attorney who is arguing that the California prohibition against samesex marriages violates the federal constitution - because his arguments depart from their state-bystate strategy for challenging prohibitions against same-sex marriage. Bob Egelko, Federal Appeals Court Takes up Gay Marriage, S.F. CHRON., Apr. 5, 2006, at B2; Wyatt Buchanan, Going for Broke in Battle over Gay Vows, S.F. CHRON., Jan. 23, 2006, at A1; see also Rubenstein, supra note 81, at 163233 (drawing a distinction between, on the one hand, "professional" public interest litigators (e.g., Lambda Legal Defense and Education Fund, the American Civil Liberties Union's Lesbian and Gay Rights Project, the National Center for Lesbian Rights, and Gay and Lesbian Advocates and Defenders) and "occasional" civil rights lawyers, on the other), 1680 (suggesting "modifications in the Model Rules concerning the scope of representation, competence, and client loyalty [that] would loosen the individualist hold on professional ethics and enhance a vision of expertise-based professionalism”). 
the "experts" take over "the role of the doorkeeper who, without really blocking the entry, shelters the Nothing onto which the door opens." 88

Predictably, this approach has produced decidedly mixed results. ${ }^{89}$ It is in the interest of the heterosexual majority - or, at the very least, of those heterosexuals who wield

88 AGAMBen, HOMO SACER, supra note 14, at 54; see also id. at 133 ("In the final analysis, however, humanitarian organizations - which today are more and more supported by international commissions - can only grasp human life in the figure of bare or sacred life, and therefore, despite themselves, maintain a secret solidarity with the very powers they ought to fight."). Rubenstein claims that "professional civil rights attorneys are often the only attorneys who are actually appointed by and answerable to their communities," and are, therefore, "less, not more, likely to undermine the political processes of those communities." Rubenstein, supra note 81, at 1668. Interestingly, Urvashi Vaid has similarly criticized small, homogeneous groups of elites for being unrepresentative, self-appointed spokespersons for the movement, asserting, in contrast, that the Human Rights Campaign, the National Gay and Lesbian Task Force, and similar organizations are "accountable" to the lesbian and gay community. URVASHI VAID, VIRTUAL EQUALITY: ThE MAinstreaming OF GAY AND LESBian Liberation 213-18 (1995). Just a few pages later, however, Vaid describes how the Human Rights Campaign, the National Gay and Lesbian Task Force, and similar organizations are undemocratic; elitist; have memberships that comprise only a small fraction of the lesbian and gay community; and, in their governance, are more responsive to the demands of fundraising than to democracy. Id. at 219-23.

89 On the positive side: In 2003, we witnessed the Supreme Court's stunning reversal of its relatively recent decision in Bowers v. Hardwick, 478 U.S. 186 (1986), when it struck down criminal prohibitions against sodomy on federal constitutional grounds in Lawerence v. Texas, 539 U.S. 558 (2003). Then, not even a year later, in Goodridge v. Department of Public Health, 798 N.E.2d 941 (Mass. 2003), see also Opinions of the Justices to the Senate, 802 N.E.2d 565 (2004), the Massachusetts Supreme Judicial Court extended the right to marry to same-sex couples in Massachusetts on state constitutional grounds. Several other states have enacted domestic partnership or civil union regimes that provide a measure of legal recognition to lesbian and gay couples, including California, Connecticut, Hawaii, Maine, New Jersey, and Vermont. Act Concerning Civil Unions, 2005 Conn. Legis. Serv. P.A. 05-10 (S.S.B. 963) (West); Act to Promote the Financial Security of Maine's Families and Children, 2004 Me. Legis. Serv. Ch. 672 (H.P. 1152) (L.D. 1579) (West); Anthony C. Infanti, Tax Protest, "A Homosexual," and Frivolity: A Deconstructionist Meditation, 24 ST. LOUIS U. PUB. L. Rev. 21, 50-56 (2005) [hereinafter Infanti, Tax Protest].

On the negative side: These high profile legal successes have been matched by equally highprofile failures. In response to a 1993 decision of the Hawaii Supreme Court that, for the first time, raised the specter of legalized same-sex marriage in the United States, Congress passed, and President Clinton signed into law, the Defense of Marriage Act, Pub. L. No. 104-199, 110 Stat. 2419 (1996). All but a small handful of states have enacted statutory, constitutional, or statutory and constitutional prohibitions against same-sex marriage. NAT'L GAY \& LESBIAN TASK FORCE, ANTi-Gay Marriage Measures in the U.S. aS OF NOvember 15, 2005, http:// www.thetaskforce.org/downloads/marriagemap.pdf. Thirteen of the constitutional amendments prohibiting same-sex marriage were approved in 2004 - all of them by wide margins, ranging from 57\% to 86\% voting in favor. Alan Cooperman, Same-Sex Bans Fuel Conservative Agenda, WASH. Post, Nov. 4, 2004, at A39; Matthew Franck, Constitution Now Bans Gay Marriage, ST. LOUIS PosTDisPatch, Sept. 2, 2004, at C1; Michael Kranish, Gay Marriage Bans Passed; Measures OK'd in All 
power and wish to maintain and enhance that power - to keep lesbians and gay men continually occupied with the task of gaining entrance through the already open door to the law. When the heterosexual majority from time to time accepts the arguments that we proffer, it merely encourages us to continue with our strategy of constant self-vigilance, which is interrupted only by the occasional cloying supplication for a peek at the light emanating from the open door to the law. In the end, we are afforded enough success to keep us engaged, but never enough to allow us to be truly successful. The doorkeeper employed a similar tactic to, at least from his perspective, keep the man from the country continually occupied with the task of gaining entrance through the already open door to the law:

The doorkeeper often engages [the man from the country] in brief conversation, asking him about his home and about other matters, but the questions are put quite impersonally, as great men put questions, and always conclude with the statement that the man cannot be allowed to enter yet. The man, who has equipped himself with many things for his journey, parts with all he has, however valuable, in the hope of bribing the doorkeeper. The doorkeeper accepts it all, saying, however, as he takes each gift: "I take this only to keep you from feeling that you have left something undone." 90

By engaging the law (and, by extension, the heterosexual majority who created it) on its own terms, we affirm its power over us and legitimize its treatment of us:

It is almost as if, starting from a certain point, every decisive political event were doublesided: the spaces, the liberties, and the rights won by individuals in their conflicts with central powers always simultaneously prepared a tacit but increasing inscription of individuals' lives within the state order, thus offering a new and more dreadful foundation for the very sovereign power from which they wanted to liberate themselves. ${ }^{91}$

And the heterosexual majority derives a tangible benefit from keeping lesbians and gay men in thrall to the law. As homines sacri, the embodiment of the virtual state of exception,

States Where Eyed, Boston Globe, Nov. 3, 2004, at A22; Voters Approve Ban on Same-Sex Unions, L.A. Times, Sept. 19, 2004, at A35.

Naturally, these illustrations are no more than that; they are not meant to provide an exhaustive list of the movement's legal successes or its failures. It is also worth noting that the tentative nature of our legal progress is only underscored when we consider our successes and failures in light of advances on the international level. When our progress is viewed from this wider perspective, it becomes clear that the United States is far from being a leader (and, in fact, is only slowly becoming a follower) in recognizing and remedying lesbian and gay rights issues. Infanti, Tax Protest, supra, at 44-49.

For further discussion of the tentative nature of our progress toward achieving unqualified acceptance by the heterosexual majority, see Anthony C. Infanti, Everyday Law for Gays and Lesbians: An Introduction 3-11, available at http://ssrn.com/abstract $=766584$.

${ }^{90}$ KAFKA, supra note 70, at 213-14.

91 Agamben, Homo SACER, supra note 14, at 121. 
lesbians and gay men are the "unnatural" and "unholy" figures that give content and meaning to the general rule of heterosexual privilege, allowing heterosexuals to affirm their own worth (and superiority) by being assured that their (hetero)sexual orientation is natural, normal, and divinely inspired. In fact, to paraphrase Agamben's astute observation, heterosexual privilege "nourishes itself on this exception and is a dead letter without it." 92

Let us return for a moment to the example of same-sex marriage to illustrate the point. Once the relationship between heterosexuals and homosexuals is shown to be one of general rule and exception, it is possible to understand why some heterosexuals might view same-sex marriage as a threat to "traditional" marriage. If same-sex marriage were put on truly equal footing with "traditional" marriage, "traditional" marriage would become a "dead letter." There would no longer be "traditional" marriage and same-sex "marriage"; there would just be marriage - without quotation marks or qualifiers. In the eyes of some heterosexuals, "traditional" marriage might then be sapped of meaning, because it would lack an authentic exception ${ }^{93}$ that could serve as a point of distinction or opposition and that, therefore, could give content and meaning to the privileges that currently attend their presumed exclusive access and entitlement to full marital status. ${ }^{94}$

So, it is not in the interest of the heterosexual majority (or, again, at the very least, of those heterosexuals who wield power and wish to maintain and enhance that power) simply to let lesbians and gay men pass freely through the already open door to the law. It $i s$, however, in their interest occasionally to reassure lesbians and gay men that efforts to pass through that door are not made in vain — in order that heterosexuals might maintain les-

${ }^{92} I d$. at 27; see also supra note 26.

${ }^{93}$ It is true that the unmarried (straight and gay) would continue to provide a point of distinction that might be seen as giving meaning to the privileges attendant to marriage. However, it might just as well be said that the benefits of marital status become diluted and marital privilege becomes indistinct once everyone is afforded full and equal access to marriage. Given the strong social norm of monogamous coupling within marriage, the difference between married and unmarried is not so much one of rule and exception, but is more akin to evolutionary stages - in other words, it is socially expected that every eligible single will at some point find a mate and marry. Thus, the line that has implicitly given meaning - and that, for more than a decade now, has explicitly given meaning - to marital privilege is not the line between married and unmarried, but the line between those who can marry (whether, at any moment, they actually happen to be married or not) and those who cannot marry.

94 Through no fault of its own, Massachusetts, which is currently the only state that legally recognizes same-sex marriage, has created a less than fully equal marital status for same-sex couples. Due to the enactment of DOMA, the federal government treats these marriages as a nullity for purposes of federal law, 1 U.S.C. $§ 7$ (2006), and permits other states to (and most, in fact, do) refuse to recognize these marriages, 28 U.S.C. $\$ 1738$ C (2006). See supra note 89. Thus, at best, Massachusetts has created an ephemeral status that has a habit of (not so magically) disappearing sometimes when couples cross the state borders and other times even while they are still within the state borders (e.g., when federal law is exerting its force on same-sex couples). 
bians and gay men in a virtual state of exception that gives content and meaning to their own pervasive privileges and reifies the righteousness of their own lives.

Perhaps, then, Agamben is correct in arguing that true change is possible only when we resist being co-opted into serving as our own doorkeeper, when we cease asking politely for entrance through a door that is already open, and when we instead turn our energies to provoking the closure of that door and the creation of a real state of exception. On more than one occasion, it has been suggested to me that government silence on the tax treatment of same-sex couples is preferable to the message that would be sent should the government choose to speak. ${ }^{95}$ But, is it really? Might it not be preferable to force the government to express in words the precise nature and the full extent of its anti-gay animus rather than allowing that animus to remain the unseen and unacknowledged (only by heterosexuals, of course) subtext of lesbian and gay lives?

In other words, the source of our great sorrow and despair - our oppression - may actually be the source of our greatest strength. By provoking the government to close the door of the law on us, we may be able to draw attention to our plight in a way that serves as a catalyst for change. Provoking the closure of the door to the law should serve as a call to action for all lesbians and gay men as well as for any potentially sympathetic straight men and women (all of whom should be horrified when they finally realize the true extent and nature of our oppression at the hands of those among them who wield power by exploiting fear and division). ${ }^{96}$ At the same time, the threat of social unrest should shock the remainder of straight society out of its complacency.

Conversely, from this perspective, the paralyzing fear of defeat - of being turned away by the doorkeeper - has been the source of our greatest weakness. Our fear has debilitated and domesticated us by turning us into our own doorkeeper:

As the evangelical warning cited by Origen concerning the interpretation of Scripture has it: "Woe to you, men of the Law, for you have taken away the key to knowledge: you yourselves have not entered, and you have not let the others who approached enter either"

95 Pat Cain, a tax professor and now Vice Provost at the University of Iowa, has been the recipient of similar suggestions. Patricia Cain, Relitigating Seaborn: Taxing the Community Income of California Registered Domestic Partners 2 (Univ. Iowa, Legal Studies Research Paper No. 05-39, 2006), available at http://ssrn.com/abstract $=881763$.

${ }^{9}$ Cf. AgAmben, Homo SACER, supra note 14, at 133 ("It takes only a glance at the recent publicity campaigns to gather funds for refugees from Rwanda to realize that here human life is exclusively considered (and there are certainly good reasons for this) as sacred life - which is to say, as life that can be killed but not sacrificed - and that only as such is it made into the object of aid and protection. The 'imploring eyes' of the Rwandan child, whose photograph is shown to obtain money but who 'is now becoming more and more difficult to find alive,' may well be the most telling contemporary cipher of the bare life that humanitarian organizations, in perfect symmetry with state power, need.”). 
(which ought to be reformulated as follows: "Woe to you, who have not wanted to enter into the door of the Law but have not permitted it to be closed either"). ${ }^{97}$

Thus, in place of our current approach of engaging the law on its own terms, we might consider using the law strategically in an effort to provoke the closure of the door to the law and, concomitantly, to destabilize heterosexual privilege. We could begin by recognizing that, despite the quotation marks that so frequently surround the phrase, the "culture war" is more than just a rhetorical device for the reactionary right. It is a very real war, and lesbians and gay men have too often found themselves the victims of reactionary violence. ${ }^{98}$ Glearly outnumbered by our foes, we might take a page from the government's playbook when it litigates against its citizens, ${ }^{99}$ and adopt (and adapt) the tactics of guerrilla warfare 100 - using the law to harass the government and provoke it to close the door to the law firmly against us - in an attempt to erode support for the hetero status quo among the "civilian" population. I realize that this probably sounds like quite a radical suggestion; yet, as we will see, it might require only the most ordinary of action to accomplish. ${ }^{101}$

Given the title of this essay and my self-professed status as a tax geek, I'm sure that you won't be surprised to learn that I think that tax would be the perfect area in which to test these guerrilla warfare tactics against the government. Despite being an area of the law that touches the life of nearly every lesbian and gay man, tax is the one door to the law that is generally left unattended by the experts who have been co-opted into serving as doorkeepers. ${ }^{102}$ As a result, tax is one area of the law where we will be able to approach the doorkeeper of the law directly, without having to pass through a gauntlet of experts attempting to dissuade us — or, worse, actively prevent us — from making our way to the already open door to the law. Approaching such a relatively unguarded door to the law may provide us the advantage of surprise in our attack (depending, of course, on who reads this essay).

In addition to being an unguarded approach, tax has particular attributes that are well-suited to its use in waging guerrilla warfare. Guerrilla warfare is associated with

97 Id. at 54.

98 See supra text accompanying notes 1 and 54-68.

99 Dunn v. Comm'r, 301 F.3d 339, 349 (5th Cir. 2002) (describing the IRS' tactics in litigation concerning the valuation of a block of stock as "guerilla warfare").

100 There was a time when critical legal scholars were accused of engaging in guerrilla warfare. Guyora Binder, On Critical Legal Studies as Guerrilla Warfare, 76 GEO. L.J. 1, 1 n.4 (1987). This analogy was rejected, however, as being a less than accurate description of critical legal studies. See id. at 8-13; David Fraser, If I Had a Rocket Launcher: Critical Legal Studies as Moral Terrorism, 41 HASTINGS L.J. 777, 781-91 (1990).

${ }^{101} \mathrm{It}$ is worth noting that there is a long tradition in the United States of using the courts as forums for protest. Lobel, supra note 81, at 493-510.

102 Cain, supra note 95, at 1 ("Taxpayers generally do not . . . use public interest law firms in the ways that civil rights groups do.”); but see supra note 85. 
"small, mobile and flexible combat groups" that engage in "long, low-intensity confrontation" to "destabilize an authority." 103 In contrast to conventional civil rights litigation, which normally involves a single or select group of plaintiffs who file suit on behalf of (even if not in the name of) a larger class or group of individuals, tax lends itself to a more diffuse approach. Although taxpayers have, on occasion, filed class action lawsuits, 104 they normally interact with the Service and the courts on an individual basis, with arguments tailored to their individual situations. ${ }^{105}$

This diffuse, individualized approach to tax controversies is perfectly suited for what has been called the "war of the flea":

"Analogically, the guerrilla fights the war of the flea, and his military enemy suffers the dog's disadvantages: too much to defend; too small, ubiquitous, and agile an enemy to come to grips with. If the war continues long enough - this is the theory - the dog suc-

103 Guerrilla Warfare, WIKIPEDIA, http://en.wikipedia.org/wiki/Guerrilla_warfare (last visited Feb. 16, 2006); see also Fraser, supra note 100, at 784-86.

104 See e.g., McGlotten v. Connally, 338 F. Supp. 448 (D.D.C. 1972) (class action seeking to enjoin the granting of tax-exempt status to organizations that exclude non-whites from membership); Green v. Kennedy, 309 F. Supp. 1127 (D.D.C. 1970) (class action seeking to enjoin the granting of tax-exempt status to schools that engage in racial discrimination).

105 See Cain, supra note 95, at 1 ("Taxpayers generally do not file class actions [or] share the expense of litigation ....").

While it is possible to prosecute a class action lawsuit seeking a refund of taxes, refund claims have been described as "individualized" and "particularly ill-suited for class certification" because of the need, under I.R.C. $\S 7422$ (a) (2006), for each class member to pay the amount of her tax deficiency and then timely file a claim for a refund. Saunooke v. United States, 8 Cl. Ct. 327, 330 (Cl. C. 1985); see also Appoloni v. United States, 219 F.R.D. 116 (W.D. Mich. 2003) (narrowing the definition of the "class" in a class action lawsuit for refund of Federal Insurance Contribution Act taxes so that it would meet the requirements of I.R.C. $\S 7422(\mathrm{a})$ ); Rose v. American Airlines, Inc., 331 F. Supp. 77, 79 (N.D. Ill. 1971) (class action claim in lawsuit challenging airport taxes stricken for failure to meet the I.R.C. $§ 7422$ requirement of individual refund claims filed by each member of the class); Agron v. Ill. Bell Tel. Co., 325 F. Supp. 487, 488 (N.D. Ill. 1970) (same with respect to class action claim in lawsuit challenging telephone taxes); McConnell v. United States, 295 F. Supp. 605, 606 (E.D. Tenn. 1969) (refusal to certify class in income tax refund action).

Subject to very narrow exceptions, the rules of the U.S. Tax Court do not appear to contemplate the possibility of a class action suit challenging the Service's assertion of a tax deficiency. Compare TAX CT. R. 60(a)(1) ("A case shall be brought by and in the name of the person against whom the Commissioner determined the deficiency (in the case of a notice of deficiency) or liability (in the case of a notice of liability) ....") and id. R. 61(a) ("No person, to whom a notice of deficiency or notice of liability has been issued, may join with any other such person in filing a petition in the Court, except as may be permitted by Rule 34(a)(1).") and id. R. 34(a)(1) (permitting a joint petition to be filed only by a husband and wife or by multiple persons who are sent a single notice of deficiency or liability by the Service) with TAX CT. R. 215 (allowing joinder of parties in declaratory judgment actions concerning retirement plans and estate tax installment payment actions), and $i d$. R. 226(a) (allowing joint petitions in disclosure actions). 
cumbs to exhaustion and anemia without even having found anything on which to close his jaws or to rake with his claws." 106

While it is easy enough for the government to close its jaws on a single lawsuit, ${ }^{107}$ imagine what would happen if thousands of domestic partners in California ${ }^{108}$ were each to file federal income tax returns splitting their earned income in accordance with the U.S. Supreme Court's decision in Poe v. Seaborn 109 and were openly to invite the Service to audit their returns and to challenge their interpretation of the law. 110 Then consider what

106 Fraser, supra note 100, at 782 n.20 (quoting Robert TABer, The WAR OF The Flea: A STUdy OF GUERRILla WARFARE THEORY AND PRACTICE 29 (1970)).

107 See Infanti, Tax Protest, supra note 89 (describing the government's treatment of a gay man who protested the treatment of lesbian and gay couples under the federal tax laws).

108 As of February 28, 2006, there are 37,283 registered domestic partnerships in the State of California. E-mail from dp@ss.ca.gov to Anthony C. Infanti, Assoc. Prof. of Law, Univ. of Pittsburgh Sch. of Law (Feb. 28, 2006) (on file with author) (this e-mail was sent in response to a request for information that I made using an online form on the domestic partner registry web page of the California Secretary of State). The State of California does not provide a breakdown between same-sex and different-sex domestic partnerships, as that "information is not required by law and cannot be asked for on the Declaration." Id. As a result, some of these partnerships may be between different-sex couples, provided that at least one member of the couple is over the age of 62. CaL. Fam. CODE $\S 297(b)(5)(B)$ (Deering 2006).

109282 U.S. 101 (1930); see 4 Boris I. BitTKER \& LAWREnCE LOKKEN, FEDERAL TAXATION OF INCOME, ESTATES AND GIFTS \& 76.1 (3rd ed. 2003).

110 See Cain, supra note 95, at 3, 16 (indicating that the time is ripe for such a challenge); see also Schwanhausser, supra note 7 (prior to the issuance of the memorandum described in the next paragraph, indicating the level of frustration among taxpayers and tax preparers as they attempted to grapple with this issue as well as the difference of opinion among tax experts over whether incomesplitting would be accepted by the courts); Mark Schwanhausser, Income-Splitting on Taxes A Gray Area, SAnJose Mercury News, Feb. 23, 2006, at 15A (same).

On February 24, 2006, the Service issued Chief Counsel Memorandum 20060838, available at http://www.irs.gov/pub/irs-wd/0608038.pdf, which addresses the reporting of earned income by California domestic partners. The Chief Counsel's Office opined that domestic partners must each report their earned income separately, taking the position that Poe $v$. Seaborn applies only to married couples. For criticism of this memorandum, see Cain, supra note 95, at 12-15, and Dennis J. Ventry, Jr., No Income Splitting for Domestic Partners: How the IRS Erred, 110 TAX Notes 1221 (2006). For a history of the attempts to get the Service to speak on this issue, see Cain, supra note 95, at 2-3, and Ventry, supra, at 1221 n.2.

This opinion was not only provided late - well into tax season and only a matter of weeks before the April 15 deadline for filing returns - but also came in a form that is prohibited by law from being cited as precedent. I.R.C. $\S 6110(\mathrm{k})(3)$ (2006); see also I.R.S. Chief Couns. Mem. 20060838 (Feb. 24, 2006) ("In accordance with $\S 6110(\mathrm{k})(3)$ this advice may not be used or cited as precedent."). If anything, this dvice (i.e., advice that is not advice - to borrow the strikethrough that is sometimes used by Agamben, see, e.g., AGAMBEn, EXCEPTION, supra note 18, at 32-40, and Derrida, see, e.g., DERRIDA, supra note 24, at 19, 44, but which did not originate with them, see 
would happen if, at the same time, thousands of married same-sex couples in Massachusetts ${ }^{111}$ were to file joint federal income tax returns, asserting that DOMA is unconstitutional, ${ }^{112}$ and likewise were openly to invite the Service to audit their returns and to challenge their interpretation of the law. ${ }^{113}$

To be clear, when I speak here of an "open" challenge, I contemplate the filing of returns that on their face challenge the current application of the tax laws to same-sex couples. Such a transparent challenge could be accomplished by filing the appropriate disclosure forms issued by the Service ${ }^{114}$ and including a cover letter with the return that ex-

Gayatri Chakravorty Spivak, Translator's Preface to DERRIDA, supra note 24, at ix, xiv - the obvious choice of form for advice to be given to those consigned to tax "limbo") only heightens the need for, and the potential success of, the guerrilla warfare tactics described in the text above. See Mark Schwanhausser, Domestic Partners to Be Taxed as Singles, SAn Jose Mercury News, Feb. 28, 2006, at $1 \mathrm{C}$ ("The memo from the office of chief counsel doesn't have the force of law, but tax experts say it sends a signal that the IRS intends to challenge domestic partners who split their income based on rules for married couples who file separately.").

111 The most recent figures are for the period from May 17, 2004 (when same-sex marriage first became legal in Massachusetts) through December 31, 2004. During that period, 5,994 samesex couples were married in Massachusetts: there were 2,123 male-to-male marriages and 3,871 female-to-female marriages. E-mail from Kevin Foster, Mass. Dep't of Pub. Health, to Anthony C. Infanti, Assoc. Professor of Law, Univ. of Pittsburgh Sch. of Law (Feb. 21, 2006) (on file with author).

112 See, e.g., Mark Strasser, Baker and Some Recipes for Disaster: On DOMA, Covenant Marriages, and Full Faith and Credit Furisprudence, 64 BROOK. L. REV. 307 (1998) (arguing that the Full Faith and Credit Clause and Due Process Clause prohibit Congress from enacting DOMA); Mark Strasser, Ex Post Facto Lawes, Bills of Attainder, and the Definition of Punishment: On DOMA, the Hawaii Amendment, and Federal Constitutional Constraints, 48 SYRACUSE L. REV. 227 (1998) (arguing that DOMA violates the Bill of Attainder Clause); Mark Strasser, Loving the Romer Out for Baehr: On Acts in Defense of Marriage and the Constitution, 58 U. PITT. L. REV. 279 (1997) (arguing that enactment of DOMA exceeds Congress' power under the Full Faith and Credit Clause, violates the right to interstate travel, and does not meet the relevant standard for displacing state domestic relations law).

${ }^{113}$ In response to a letter from a conservative, "pro-family" organization urging it to investigate and prosecute any same-sex couples that might attempt to file joint federal income tax returns, the Service reaffirmed the application of DOMA to the tax laws and summarized its position on joint filing by same-sex couples as follows:

Even though a state may recognize a union of two people of the same sex as a legal marriage for the purposes within that state's authority, that recognition has no effect for purposes of federal law. A taxpayer in such a relationship may not claim the status of a married person on the federal income tax return.

Letter from the Internal Revenue Service to Eugene A. Delgaudio (June 14, 2004), available at http://www.publicadvocateusa.org/news/article.php?article=121. For reporting on this letter, see Allen Kenney, IRS: Foint Filing Not Allowed for Same-Sex Married Couples, 103 TAX Notes 1466 (2004).

114 See infra note 118. 
plains the precise nature of the challenge. ${ }^{115}$ Surreptitious challenges simply would not have the same effect. ${ }^{116}$ Although the Service would likely uncover the income-splitting by the California couples relatively quickly and easily (because of the mismatch between the amount of earned income reported on the tax return and the amount of earned income reported to the Service by the taxpayer's employer), the Service would be far less likely to detect the filing of joint federal income tax returns by the Massachusetts couples. ${ }^{117}$ In either case, open challenges are necessary to bring about the desired adverse impact on the Service, because achieving that impact depends on the Service's immediate awareness of the challenges.

In this regard, the Service should be accustomed to, and adequately equipped for, individual challenges to its interpretation of the tax laws; in fact, as alluded to above, it has promulgated specific regulations concerning, along with the necessary forms for reporting, tax return positions that challenge rules or regulations. ${ }^{118}$ However, the nearly simultaneous arrival of thousands upon thousands of these challenges would, I imagine, leave the Service nonplussed (to say the very least). ${ }^{119}$ We could expect that this initial strike against the law would cause a disruption similar to that caused by a computer virus that is designed to bombard a single website with information until it becomes so overloaded that it is forced to be shut down temporarily. ${ }^{120}$ After this initial disruption, the

115 See, e.g., Druker v. Commissioner, 697 F.2d 46, 47-48 (2d Cir. 1982) (explaining the steps taken by taxpayers who wished to openly challenge the constitutionality of the marriage penalty).

116 For an account of the successful use of this approach to garner the attention of the San Francisco International Airport in an effort by the airport's neighbors to press for the reduction of airplane noise, see Andrew D. Freeman \& Juli E. Farris, Grassroots Impact Litigation: Mass Filing of Small Claims, 26 U.S.F. L. REV. 261 (1992).

117 See Warren Rojas, Financiers: Bush Marriage Crusade May Only Bolster Tax Inequities, 102 TAx Notes 1597, 1598 (2004) (indicating that it would be difficult for the Service to detect joint filing by same-sex couples).

118 Treas. Reg. $\S 1.6662-3(\mathrm{c})$ (as amended in 2003); id. $\S 1.6662-4(\mathrm{f})$ (as amended in 2003); Internal Revenue Serv., U.S. DeP'T OF Treasury, Form 8275: Disclosure Statement (2001), available at http://www.irs.gov/pub/irs-pdf/f8275.pdf; INTERNAL REVENUE SERV., U.S. DeP'T OF TREASURY, FORM 8275-R: REgulation Disclosure StATEMENT (2002), available at http://www.irs.gov/pub/irs-pdf/f8275r.pdf.

119 Agamben has made a similar point with regard to the arrival of individual refugees as opposed to the arrival of a mass of refugees:

What is essential is that, every time refugees represent not individual cases but - as happens more and more often today - a mass phenomenon, both these organizations and individual states prove themselves, despite their solemn invocations of the "sacred and inalienable" rights of man, absolutely incapable of resolving the problem and even of confronting it adequately.

AgAmBen, HOMO SACER, supra note 14, at 133.

120 See, e.g., MyDoom Swamps Website, L.A. Times, Feb. 2, 2004, at C5 (describing how the MyDoom virus caused the SCO Group to shut down its website). 
Service would be saddled with thousands of individual audits and the resulting court cases, which could drag on for years and significantly drain government resources.

With a bit more effort, we could turn the law even more fully against itself, while at the same time facilitating the participation of as broad a swath of the lesbian and gay community as possible in this opening salvo of the guerrilla war. We could encourage low- and middle-income as well as elderly lesbians and gay men to avail themselves of volunteer income tax return preparers who are trained and supported by the Service when preparing their returns challenging the Service's interpretation of the tax laws. ${ }^{121}$ The Service sponsors two volunteer tax return preparation programs: for low- and middle-income taxpayers, the Volunteer Income Tax Assistance program provides help in preparing basic tax returns; for the elderly, the Tax Counseling for the Elderly program provides free tax counseling and help in preparing basic tax returns. ${ }^{122}$ The sites where help is available are located throughout the country, and the Service will provide taxpayers with the location of the closest site when they call its toll-free telephone number. ${ }^{123}$

Following the initial disruption, the extended audit and litigation process would likely require the participating lesbian and gay taxpayers to employ accountants and/or attorneys to work on their behalf - all of whom would obviously be instructed to be as unaccommodating to the Service as possible (e.g., by refusing to extend the statute of limitations to allow more time for audit). For those with means, this would entail a financial sacrifice. ${ }^{124}$ Those who would find this sacrifice unduly burdensome could turn for help to attorneys and accountants who are willing to work on a pro bono basis. ${ }^{125}$ Again,

121 These taxpayers may have to stand firm and explain to the preparers that they wish to make a good faith challenge to the law. No tax preparer should refuse to prepare a return making a good faith challenge to the law if it is openly and notoriously disclosed - on forms prepared by the Service, no less. In fact, nothing in the agreement signed by volunteers prohibits them from preparing such returns. INTERNAL REVENUE SERV., U.S. DEP'T OF TREASURY, FORM 13615 : VOLUNTEER AGREEMENT (2005), http://www.irs.gov/pub/irs-pdf/f13615.pdf.

122 Internal Revenue Serv., U.S. Dep't of Treasury, Free Tax Return Preparation for You by Volunteers, http:/ /www.irs.gov/individuals/article/0,,id=107626,00.html (last visited Feb. 18, 2006).

${ }^{123} I d$.

124 No one ever said that subversion of the privileging of heterosexuality in our society would be cheap or easy:

These figures push the aporia of sovereignty to the limit but still do not completely free themselves from its ban. They show that the dissolution of the ban, like the cutting of the Gordian knot, resembles less the solution of a logical or mathematical problem than the solution of an enigma. Here the metaphysical aporia shows its political nature.

AGAMBEn, HOMO SACER, supra note 14, at 48.

125 Many tax lawyers ache to do pro bono work, but are hard put to find cases that allow them to use their tax skills. A good place to start looking might be the listing of pro bono programs maintained by the American Bar Association on its website. Am. Bar Ass'n, Directory of Pro Bono Programs, http://www.abanet.org/legalservices/probono/directory.html\#. To obtain information about accountants who provide pro bono services, see Accountants for the Public Interest, http://www. geocities.com/api_woods/api/apihome.html. 
however, an opportunity arises to turn the law even more fully against itself (and, at the same time, to facilitate the participation of as broad a swath of the lesbian and gay community as possible): low-income taxpayers could contact one of the many independent legal clinics that provide professional assistance in disputes with the Service. These clinics receive financial support from the Service and can be found in every state and the District of Columbia. ${ }^{126}$

If this initial strike were to prove successful, lesbians and gay men could then begin to educate the masses concerning their tax grievances. ${ }^{127}$ These educational activities could be followed by the expansion of our guerrilla activities into other areas of the law. Naturally, we would need to adapt our tactics as we branch out to other areas of the law, both because other areas might require different approaches and because the government would probably have adapted to (and, therefore, would likely be anticipating) the tactics that we used in the tax context. In each case, however, the goal would be the same - to provoke the closure of yet another already open door to the law.

\section{Thought-Provoking, Provoking Thought}

For decades, we have pursued a legal strategy that engages the law on its own terms and that has afforded us only the most tentative of progress toward the unqualified acceptance that we seek from the heterosexual majority. To justify our efforts, we have reassured ourselves that, over time, this strategy will win out. But what if all this time we have merely been patiently waiting outside the already open door to the law, allowing ourselves to be cast as homines sacri and to be placed in the dangerous position of serving as the exception that gives meaning to the general rule of heterosexual privilege? What if the only way out of this dangerous position is to provoke the closure of the door to the law and, concomitantly, to convert our virtual state of exception into a real one - in other words to convert the imagined threat that we pose into a very real threat to the stability of the current legal and social order? What if turning the law against itself - using the law as a tool in guerrilla warfare against those in the heterosexual majority who wield power - is the only effective means of clearing the way for a meaningful and thorough reconsideration of the appropriate relationship between sexual orientation and legal and social norms? While these questions may make us feel nervous and uncomfortable (as any truly thought-provoking questions should), we must open ourselves to thinking the possibility that the time has arrived for lesbians and gay men to radically alter their approach to effecting legal and social change.

126 Internal Rev. Serv., U.S. DeP'T of Treasury, Publ'N No. 4134, Low Income TAXPAYER CLINIC LIST (2005), available at http://www.irs.gov/pub/irs-pdf/p4134.pdf.

127 Fraser, supra note 100, at 786 ("After [a guerrilla band's] initial successes, it sets about to educate the masses ...."). 